\title{
СОЦИОКУЛЬТУРНАЯ ДИНАМИКА
}

удК 316.7

Н.А. Хренов

Москва

\section{СОЦИОЛОГИЧЕСКИЙ ПОВОРОТ В НАУКЕ ОБ ИСКУССТВЕ ХІХ В.: КОНЦЕПЦИЯ И. ТЭНА КАК ПРЕДВОСХИЩЕНИЕ КУЛЬТУРОЛОГИЧЕСКОГО ПОВОРОТА*}

Цитирование: Хренов Н.А. Социологический поворот в науке об искусстве XIX века: концепция И. Тэна как предвосхищение культурологического поворота // Наследие. 2021, № 1(18). - С.9-36.

DOI: https://doi.org/10.31119/hrtg.2021.1.1

Citation: Hrenov N.A. Sociologicheskij povorot v nauke ob iskusstve XIX veka: koncepciya I. Tena kak predvoskhishchenie kul'turologicheskogo povorota [Sociological turn in the science of arts of the XIXth century: the concept of H. Taine as an anticipation of the cultural turn] // Nasledie [Heritage]. 2021, No. 1 (18). pp.9-36.

DOI: https://doi.org/10.31119/hrtg.2021.1.1

Методологический «бум» в сфере изучения искусства, характерный для второй половины XX в., - следствие возникновения большого числа новых наук и активизации наук и научных направлений, появившихся с начала Нового времени. Первоначально это был «бум» философский, о чем свидетельствовала, например, практика энцииклопедистов во Франщии ХVIII в. Затем одна

* Окончание. Первые две части см. в журнале «Наследие» № 1(16) и 2(17) за 2020 г.

(C) Хренов Н.А., 2021 
за другой появились такие науки, как эстетика, сочиология, психология, семиотика. Активизировались лингвистика, филология и такое традиционное философское направление, как герменевтика. Позднее нарастал интерес к феноменологии. И, наконец, во второй половине ХХ в. рождается и переживает бурное развитие наука о культуре, в которой развертывается синтез возникиих ранее наук и научных направлений, а, кроме того, на почве новой науки в особые отношения вступают естественные и гуманитарные науки. Открытие культуры как предмета научного исследования - одно из наиболее ярких событий истории науки XX и XXI вв. Можно утверждать, что в этой истории произошел культурологический поворот. Однако в истории науки этот глобальный поворот имел предысторию в виде эстетического и сочиилогического поворотов. Статья посвящуена одному из таких поворотов - сочиологическому. Свое наиболее полное выражение этот поворот получил в работах французского исследователя ХІХ в. Ипполита Тэна, посвященных искусству. Анализируя сочинения И. Тэна, автор стремится продемонстрировать обращуающий на себя внимание факт - попьттку объяснить природу искусства не только с помощьью тех представлений, что к этому времени сложились в эстетике и вообще в гуманитарных науках, но и с помощью методов, характерных для естественных наук. Иначе говоря, имея в виду методологию И. Тэна, автор пытается показать вклад позитивизма в познание искусства. Вторжение позитивизма в процессы познания искусства вовсе не характеризует лишь науку XIX в. В очередной раз активность позитивизма проявилась в середине $X X$ в. и стала уже традицией. Позитивизм оказал влияние также и на становление науки о культуре. Фундаментальные идеи П.А. Сорокина к этому имеют самое прямое отношение. Данная статья мыслится автором как часть фундаментального исследования, название которого видится ему как «История истории искусства», т.е. история становления методологии изучения искусства.

Ключевые слова: позитивизм, культурологический поворот, соччиологический поворот, история искусства, история истории искусства, социология искусства, психология искусства, эстетика, естественные науки, гуманитарные науки, история искусства без имен, культура чувственного типа, культура идеационального типа, Тэн, Спенсер, Конт, Гегель, Сорокин, Дюркгейм, Гизо, Бокль, Дюбо, Кребер, Фуко, Шпенглер, ичиилизация, смерть автора, культурология, наука об искусстве, линейный принциип, цуиклический принциип.

Hrenov N.A. Sociological turn in the science of arts of the XIXth century: the concept of $\mathrm{H}$. Taine as an anticipation of the cultural turn

Methodological boom in the studies of arts, typical for the second half of the twentieth century - a consequence of the emergence of a large number of new sciences which enhanced research directions that have emerged since the beginning of the New Era. Originally it was a philosophical, guided by the practice of Encyclopaedists in France of the XYIIIth century. Then, one after another appeared such sciences as aesthetics, sociology, psychology, semiotics. Linguistics, philology and such traditional philosophical direction as hermeneutics became more active. Later there appeared growing interest in phenomenology. And finally, in the second half of the twentieth century the science of culture was born and has underwent rapid development, synthesizing previous sciences and scientific directions and in addition developing on their basis the new science, natural and human of special relations. Culture as a subject of scientific research is one of the most striking events in the 
history of science of the XX and XXI centuries. In the history of science this global turn has the prehistory in the form of the aesthetic and sociological turn. The article is devoted to one of these turns - sociological. This turn received its most complete expression in the works of the French researcher of the XIX century Hippolyte Taine devoted to arts. The author attempts to explain the nature of arts using not only those ideas that have developed by this time in aesthetics and in humanitarian sciences, but also with the help of methods of natural sciences. In other words, referring to the methodology of $H$. Taine the author tries to show the contribution of positivism to the knowledge of arts. The invasion of positivism in the processes of knowledge of arts does not characterize only this science of the XIX century. The activity of positivism was manifested in the middle of the twentieth century and became a tradition. Positivism influenced the formation of the science of culture too. P.A. Sorokin's fundamental ideas have the most direct connection with this. This article is considered by the author as the part of a fundamental study, which the author entitles "the history of the history of arts», i.e. the history of the formation of the methodology of arts studies.

Key words: positivism, cultural turn, sociological turn, history of arts, history of arts history, sociology of arts, psychology of arts, aesthetics, natural sciences, history of arts without names, culture of the sensual type, culture of the ideational type, Taine, Spencer, Comte, Hegel, Sorokin, Durkheim, Guizot, Buckle, Kroeber, Foucault, Spengler, civilization, death of the author, cultural studies, science of arts, linear principle, cyclic principlel

\section{0. Эстетический поворот как выражение духа}

индивидуализации искусства в последние столетия .

\section{Вкус между эстетикой и культурологией}

Констатируя зависимость искусства от духовных и физических причин, от изменяющихся от поколения к поколению идей и настроений, что является предметом размышлений Тэна, мы не могли не затронуть и тему о вкусах, причем не индивидуальных, а общественных. А раз общественных, то, следовательно, являющихся предметом прежде всего эстетики или философии искусства. Тут тоже можно говорить о преемственности в представлениях и в использовании понятий. В данном случае имеется в виду традиция Дюбо. ХХ в. теряет тот преувеличенный интерес к вкусу, который с середины XVIII в. привлекал внимание многих мыслителей Европы, что не удивительно, ведь интерес к вкусу выражал открытие целой сферы прекрасного, а это открытие было следствием распространяющегося в высших сословиях эпикуреизма. Становление индустриального общества и, в частности, в том отрезке истории, что обозначен XIX в., кажется, это настроение сильно смягчило. Тем не менее понятие вкуса в литературе все же сохранялось, и об этом свидетельствовали опять же сочинения Тэна. Ведь Тэн, как мы уже отмечали, этим понятием пользуется, чему не приходится удивляться, поскольку в начале первой главы «Философии искусства» он, представляя новую дисциплину - социологию, еще затрудняется определить ее границы. То направление, в границах которого следуют его суждения и анализы, он определяет как эстетика или, как он сам уточняет, философия искусства [Тэн, 1933, с.8]. И осознание им своего метода, как и приемов, используемых им, свидетельствует о том, что возникшие в XX в. новые научные направления лишь находятся в ситуации становления. 
Правда, говорит Тэн, это новая и особая эстетика, поскольку она отказывается навязывать правила. Эта эстетика констатирует законы и отличается историзмом. В этой эстетике все определяет плюрализм. Ни один стиль она не противопоставляет другим. Хорошо бы, если бы было так. Но почему же в этом случае он в выборе эпох в истории искусства оказывается очень разборчивым? Новая эстетика, как он полагает, лишь устанавливает зависимость стилей от человеческого духа. С другой стороны, зависимость искусств от среды для Тэна предстает и как зависимость его от публики, но в свою очередь публика ставится в зависимость от вкуса. Понятие вкуса у Тэна активно применяется. Но такая зависимость публики от наличия вкуса была, как мы помним, уже у Дюбо. Следует отметить, что Дюбо интересует лишь та разновидность публики, которой присущ вкус. Он, например, выступает против включения в состав публики той категории людей, которые не способны высказать свое мнение об искусстве и не могут судить о степени совершенства художественного произведения. Иначе говоря, это люди, у которых вкус отсутствует. «Публика, о которой идет здесь речь, - пишет Дюбо, - ограничивается, стало быть, лишь теми людьми, которые читают книги, ходят на спектакли, любуются картинами и беседуют о них, а также теми, кто каким бы то ни было путем овладел той манерой рассуждения, которую именуют вкусом к сравнению...» [Дюбо, 1976, с.437].

Читая внимательно Тэна, можно констатировать следующие особенности применяемой им методологии при исследовании искусства. К одной из таких особенностей можно отнести то, что он прибегает к сопоставлению разных эпох в истории западного искусства. Прежде всего, к сопоставлению современной ему эпохи с эпохой Ренессанса. К следующей особенности мы можем отнести сопоставление им разных культур и прежде всего культуры античной и культуры западной. Наконец, каких бы культур и периодов он ни касался, его внимание приковано к двум ситуациям в истории. Это ситуация подъема и ситуация упадка искусства. Такая ориентация в истории помогает применительно к искусству испробовать принцип историзма. Пытаясь выявить в каждом конкретном случае зависимость искусства от среды, он каждый раз обязан выявлять специфическое состояние общества, которое не остается неизменным. «... Если великое искусство и окружающая его среда существуют одновременно, то связь между ними не случайна, так как вторая зарождается, развивается, достигает зрелости, портится и разлагается вместе с первым, каковы бы ни были случайности в людском водовороте и какие бы своеобразные и неожиданные формы ни принимало творчество отдельных художников, - пишет Тэн в «Философии искусства». - Среда уносит или приносит искусство вслед за собой, подобно тому, как изменения температуры заставляют падать росу или уничтожают ее, подобно тому, как яркий свет питает, а тусклый заставляет блекнуть зелень растений» [Тэн, 1933, с.35].

Нельзя утверждать, что Тэн решил своим подходом продемонстрировать то, что сегодня кажется азбучной истиной. Совсем нет. Стоит открыть сочинения уже процитированного нами А. Кребера, чтобы убедиться, что все эти поставленные Тэном вопросы продолжают интересовать и исследователей ХХ в. Другое дело, что у современных исследователей, в частности у того же А. Кребера, все эти вопросы ставятся уже не так, как ставил их в XIX в. Г.Т. Бокль, т.е. применительно к цивилизации, и не так, как это происходит в сочинениях Тэна, а в соотнесенности 
с культурой. Но ведь во времена Тэна это тоже не такая уж и неожиданная новость, поскольку аналогичная постановка вопроса имела место в конце XVIII в., а именно в вышедшем в 1791 г. сочинении И.Г. Гердера «Идеи к философии истории человечества». «Культура народа, - писал И.Г. Гердер, - это цвет его бытия, изящное, но бренное и хрупкое откровение его сущности» [Гердер, 1977, с.388]. Если какой-либо народ по какой-то причине в культурном развитии отстает, он в общении с другими народами, находящимися на более высоком уровне развития, учится. Как и человек, культура рождается и умирает. С этим, по мысли Гердера, связаны расцвет и упадок искусства. Понятно, что у Гердера история человечества предстает историей культуры и, еще точнее, историей культур. Может быть, даже Гердер не был первым, кто пытался представить историю историей культуры. Так, касаясь этого вопроса, А. Гулыга первым все же таким образом представляющим историю называет совершенно забытого в наше время немецкого историка и лингвиста Иоганна Кристофа Аделунга, выделявшего в своей характеристике культуры несколько признаков: уменьшение роли физической силы, постепенное сокращение господствующей роли чувственного познания и неосознанных понятий, увеличение роли сознания и разума, смягчение нравов, воспитание вкуса [Гулыга, 1977, с.626].

Пытаясь понять метод исследования искусства Тэна, мы, кажется, объяснили особенности его сочинений. Но, как нам представляется, с Тэном не все так просто. Ведь в XIX в. наука, в том числе и социология, и историческая наука, находятся в процессе становления. Еще не существует устоявшихся понятий и категорий, как не существует вполне сложившихся подходов. Это означает, что какие-то проблемы, стоящие в центре отдельных наук, перетекают в другие науки и осмысляются в соответствии с характерными для них подходами. Поэтому вполне можно допустить, что и метод Тэна несет на себе печать этой неопределенности. Так, следуя позитивистской методологии, Тэн выходит в пространство других наук, например психологии, что в литературе отмечается, и в то же время для его взгляда характерно уже то, что будет обсуждаться в границах еще не возникших наук. Так, несмотря на уверения Тэна по поводу соотнесенности его метода с эстетикой, Ш. Лало, тем не менее, ему в этом отказывает. Отказывает на том основании, что эстетика занимается исключительно индивидуальным аспектом в искусстве, тогда как Тэна интересуют проекции на произведения искусства и их творцов тех установок и настроений, которые существуют в обществе. Но, отказывая Тэну в причастности его метода к эстетике, Ш. Лало готов его метод «прописать» по ведомству психологии. «Сто раз повторено, - пишет Ш. Лало, - что его метод - это психология народов или, по крайней мере, психология публики, а не психология индивидуумов, и в особенности наиболее оригинальных личностей, гениальных творцов, которые по самому определению ускользают от анализа. Но так как теоретиков эстетики занимают главным образом и даже исключительно личности гениальные, то можно сказать, что тэновский метод - метод социологический, а не эстетический; и чем более он его углубляет, тем более он поворачивается спиной к истинному предмету эстетики, т.е. к личностям творцов и художественным произведениям, возвышающимся над посредственностью, которые по самому своему определению или по самой своей функции отличаются от посредственности и не могут быть из нее выведены» [Лало, 1915, с.197]. 
Тяготение Тэна к психологии отмечает не один Ш. Лало. Так, давая характеристику методологии Тэна, Э. Геннекен - один из тех, кто попытался выделить в критике эстетический, психологический и социологический аспекты, - тоже отмечает тяготение социолога Тэна к психологии. «Все труды Тэна, - пишет он, - отмечены одним стремлением - рассматривать историю литературы в связи с психологией. Он старается уяснить сущность исторического метода и доказать, что целая серия исторических документов, почти отброшенных, отлично может послужить для того, чтобы понять людей и прошлого, и настоящего времени. Поэтому он собирает факты, берет рассказы, анекдоты, исторические речи и литературные документы, излагает все это и уясняет, обобщает и заключает, стремится, одним словом, дать картину нравов, не делая оценки личностей, не защищая и не обвиняя. Он анализирует и уясняет - вместо того, чтобы хвалить; он резюмирует - вместо того, чтобы порицать. Он изучает произведение искусства не само по себе, а как характеристику, как символ, поясняющий человека и народ, который подлежит его изучению» [Геннекен, 1892, с.11].

Сам Тэн пишет, что его целью является не только выявление состояния умов, но и склад характера людей той или иной эпохи, природные инстинкты, первоначальные страсти, сила чувств, степень энергии, привычки и потребности [Тэн, 1933, c.92]. Но психология как наука соотносится с личностью, с индивидуальным началом. Это ее выделяет в системе остальных наук, что делает ее более близкой к искусству. Психология ассоциируется с той индивидуальной стихией, выразителем которой и является искусство. Так, сопоставляя психологию и культурологию, А. Кребер пишет: «Если нас интересуют в первую очередь свойства личностей, мы будем заниматься психологией и обращаться к культуре только как к совокупности данных, которые нельзя полностью исключить из рассмотрения. Если же главным образом нас интересует культура и то, как она себя ведет, мы постараемся отвлечься от персоналий, принимая их только в качестве неизменных механизмов или средств выражения культуры» [Кребер, 2004, с.15].

Отвлечение от персоналий - это та же самая формула «без имен» только в вельфлиновском варианте. В связи с этим не может не возникнуть вопрос: а не является ли поворот, который произошел в XIX в. и который мы называем социологическим, уже предвосхищением поворота культурологического? Только этот социологический поворот извлек из всего веера культурных проблем один и приблизил его к читателю. Иначе говоря, социологический поворот оказался ступенью к осознанию последующего поворота. Ведь, пытаясь обнаружить в истории культуры прецеденты современной ему культуры, Тэн одновременно находит и альтернативные ей культуры, которые в его рефлексии предстают идеалом, т.е. такой реальностью, которая возможна в истории в будущем. Тэн уже ощущает развертывающуюся в XIX в. смену культур и потому позволяет себе параллели, обращающие на себя внимание несходством с XX в. Выше мы отметили, что история культуры, если ее окинуть взглядом исследователя, существующего в культуре чувственного типа, предстает в то же время и историей культуры идеационального типа. Но только в эпоху цветения культуры чувственного типа она вытесняется на периферию и уходит в бессознательное. Но ведь то же самое происходит и с культурой чувственного типа в эпохи, когда доминантой культуры становится сверхчувственная стихия. 
По поводу сокращения в поздней культуре роли чувственного познания Тэн постоянно высказывается, констатируя переизбыток мозговой и, следовательно, активности понятийных форм в современной ему культуре. Но это сокращение он воспринимает и оценивает катастрофой, и в этом он продолжает установки романтиков. А вот что касается вкуса как показателя качества культуры, то у него это тоже усвоенный урок из опыта XVIII в. Ведь это мыслители галантного века со свойственными этому веку эпикурейскими установками открыли данную проблематику и, как мы убеждаемся, превратили ее в значимый элемент культуры. Потом, в ХХ в., это повторит и подтвердит Й. Хейзинга, ссылаясь на Я. Буркхардта. Так, в его видении культуры на первом месте оказывается не социально-экономическое, а эстетическое начало. Он пишет: «Тот факт, что Я. Буркхардт в своем представлении о культуре на первое место ставит ее эстетическую сторону, не должен нас удивлять» [Хейзинга, 2010, с.214]. В конце концов он солидаризируется с Я. Буркхардтом. Выделяя эстетическую сферу в качестве основополагающей для культуры, Й. Хейзинга в то же время противопоставляет ее научному и техническому, т.е. цивилизационному аспекту. «Мы все слишком хорошо знаем, что высокая степень научного и технического совершенства не является гарантией культуры. Для этого необходимы: прочный правовой порядок, нравственный закон и человечность - основные устои общества, которое и является носителем культуры. Наряду с этим наше представление об определенной культуре будет связано в первую очередь с достижениями в эстетической сфере, с произведениями искусства и литературы» [Хейзинга, 2010, с.214].

Но, как свидетельствуют сочинения Тэна, именно им этот опыт XVIII в. усвоен и утвержден. С эстетикой, стало быть, все ясно. Без эстетической, т.е. игровой, по Канту, стихии культуру не объяснить, а более всего - не объяснить пик каждой культуры, получающий выражение прежде всего в «человеке играющем», а следовательно, в искусстве. Остановимся более подробно на двух явлениях, оказывающихся в центре внимания Тэна. Во-первых, на том, что позднее К. Леонтьев, на которого позитивизм в лице Спенсера также оказал влияние, назовет «цветущей сложностью культуры», и, во-вторых, на том, что позднее с легкой руки Ф. Ницше будут называть декадансом. Подъем и упадок в истории какого-либо народа, будь это Италия, Нидерланды, Англия или Франция XIX в., постоянно сменяют друг друга. Что является причиной невероятной вспышки чувства прекрасного у греков в эпоху «античного Просвещения», т.е. в эпоху Платона и Аристотеля, или в эпоху Медичи в Италии? И как можно объяснить тот упадок, который спустя какое-то время (не такое оно уж и длительное, что так удивляет А. Кребера, обратившего на это внимание, когда он пытается понять кратковременность периода расцвета трагедии) наступает? «Весь путь развития греческой драмы уместился в два столетия, - пишет А. Кребер. - Слава греческой трагедии приходится на период продолжительностью менее столетия» [Кребер, 2004, с.748].

Сколько поколений длится этот расцвет искусства у греков? А у итальянцев XV и XVI вв.? На этот вопрос Тэн дает краткий, но, трудно сказать, верный ли ответ. Расцвет, а речь идет о Ренессансе, по Тэну, охватывает лишь период с последней четверти XV в., и он продолжается первые тридцать или сорок лет XVI в. И еще более точно: длительность расцвета - 50 лет. Тэн предельно точен. «Пространство это резко отграничено; если вы сделаете шаг вперед или назад от него, то найдете по эту 
сторону незаконченное искусство, а по ту - искусство испорченное...» [Тэн, 1933, c.61]. Это потом Й. Хейзинга усложнит проблему и поколеблет ясность, которой обладал Тэн в вопросе о границах Ренессанса. Вот в этот краткий период создают свои шедевры Леонардо, Микеланджело, Рафаэль, Джорджоне, Тициан, Корреджо и т.д. «Раньше - искусство пускает первый росток, после - искусство увядает; расцвет приходится на промежуток между двумя периодами и длится около пятидесяти лет» [Тэн, 1933, с.61]. Да, нет в данном случае. Несмотря на то, что Тэн следует Гегелю и, следовательно, вроде бы вынужден продемонстрировать схему истории искусства «без имен», он, тем не менее, называет «имена», в том числе тех, кто предшествует Леонардо и Рафаэлю - и Филиппо Липпи, и Доменико Гирландайо, и Андреа Веррокио, и тех, кто безуспешно будет подражать в эпоху упадка величию гениев, Каррачи и т.д.

Что же происходит в Италии XV и XVI вв.? С чего начинается этот Ренессанс? Ведь Тэн, прежде чем что-то сказать об искусстве этих столетий, обязан дать характеристику состояния того социума, что имел место во Флоренции, Риме или Неаполе. Такой уж у него метод. Чтобы появилось то великое искусство, которое мы знаем, должна была измениться и психология человека. Тэн так и пишет: «Нужно было, чтобы религия приспособилась к новой психологии человека. Она была вынуждена ограничить себя, отменить или смягчить проклятия, которые она посылала земле, узаконить или терпеть природные инстинкты, признать открыто или посредством разных обходов весь расцвет мирской жизни, не подвергать более осуждению научного исследования и стремления к благосостоянию» [Тэн, 2008а, с.228]. Но что значит «терпеть природные инстинкты»? А это целая революция. «Нельзя было больше смотреть на мир как на темницу и на человека как на земляного червя, а на природу как на хрупкое и временное покрывало, плохо натянутое между Богом и человеком и позволяющее там и сям, сквозь свои прорези, видеть сверхъестественный мир, единственно и сущий, и прочный» [Тэн, 2008a, с.229].

Как в новой ситуации примирить природные инстинкты и религиозные установки? Это уже когда-то пытались делать. Например, об этом свидетельствует философия Эпикура, которая в Италии вновь становится востребованной. И об этом свидетельствует трактат Л. Валлы «Об истинном и ложном благе» [Валла, 1981, с.80]. Он доказывает, что эпикуреизм вовсе не противостоит христианству, во всяком случае, не должен. Не случайно, давая характеристику итальянского общества времен Ренессанса, Тэн постоянно вспоминает эпикуреизм греков. «Здесь, - пишет он, - просвечивает в возобновленном язычестве эпикурейская веселость, желание наслаждения во что бы то ни стало и немедленно, и тот инстинкт удовольствия, который строгая философия и суровость политических обстоятельств до сих пор умеряли и сдерживали» [Тэн, 2008б, с.103]. Говоря о Флоренции, он отмечает ее «эпикурейские уроки» [Тэн, 2008б, с.20] или говорит об «эпикурейских нравах» опять же Флоренции [Тэн, 2008б, с.75]. Попробуй объясни тягу итальянцев к прекрасному, вообще, всю эту вспышку искусства без возрождения эпикурейской психологии. Ведь и в XVIII в. эстетика возникла именно потому, что возродились и активизировались эпикурейские настроения. Откуда появился кантовский гедонизм, который он положил в основу эстетики, как не от эпикуровской традиции? Вот, скажем, Дидро параллельно публикации своего трактата по эстетике [Дидро, 1980, с.93] в очередном 
выпуске «Энциклопедии» печатает статью об Эпикуре [Дидро, 1925], извлекая уже в который раз в истории это имя из забвения.

Только вот любопытно было бы поставить вопрос, до каких пор этот самый превозносимый Л. Валлой, а вслед за ним позднее и Тэном, пытающимся осмыслить состояние цветущей Флоренции и полагавшим, что эпикуреизм в этом состоянии сыграл не последнюю роль, является исключительно позитивным и способствует подъему духа и творчества и когда он оборачивается своей противоположностью, объясняя распространение распущенности, разврата и насилия, и когда для того, чтобы ему противодействовать, его остановить, требуются такие фанатики, как Савонарола, во многом способствовавший угасанию этого негативного разлива эпикуреизма. Давая характеристику итальянского искусства XV в., Тэн констатирует присутствие вкуса не только у выдающихся художников, но и окружающих их множества знатоков, покупателей, обширной публики, состоящей не только из дворян и ученых, но из мещан, ремесленников, монахов, простонародья. «... Великие вкусы этой эпохи были, естественно, стихийны, всеобщи, и весь город помогал своею отзывчивостью и пониманием созданию художественных произведений, подписанных именами великих мастеров» [Тэн, 1933, с.67]. Так расцвет искусства во Флоренции выражал общее состояние умов, эстетический вкус, распространившийся во всех слоях общества. Без эстетического поворота, что происходит в XVIII в., движение в сторону открытия культуры как предмета исследования не объяснить, поскольку игра - выражение духа культуры.

Правда, в XIX в. этот игровой дух постепенно утрачивается, чего не скажешь о XVIII в. Распространение этого игрового духа тогда свидетельствует также и о новом открытии личного начала, об углублении в природу индивидуального начала. Куда же все это делось в XIX в.? Эти изменения не могли пройти мимо внимания Тэна. «Все современное искусство, совершенно личное и обнаруживающее особую индивидуальность, которая есть индивидуальность художника, - в противоположность искусству античному, совершенно безличному и открывающему некоторую вещь общего характера, а именно город... Все более и более искусство становится исповедью - исповедью индивидуальной души, которая высказывает себя и делается вся целиком зримой для повсюду рассеянного, неопределенного множества других душ» [Тэн, 20086, с.134]. Вот это самое усиление индивидуализации за счет разрыва с коллективной стихией как раз и делает актуальным обсуждение вопроса об обращении исследователя к еще одной науке - психологии. И об этом в связи с Тэном невозможно не говорить.

Социология - наука, возникшая вместе с появлением индустриального общества, и она была обязана осмыслить уже не только чисто эстетические и гедонистические функции искусства, которые в XVIII в. интересовали в первую очередь, но и любые другие социальные функции. Из этого и следует исходить, анализируя концепцию Тэна. С другой стороны, совершенно очевидно, что Тэн не порывает и с теми модными для предшествующих столетий проблемами, которые часто сосредоточивались вокруг понятия «вкус». Хотя в массовом обществе, и, в частности, на раннем его этапе, а это и есть XIX в., вкус заметно трансформировался, а ставшая основанием для разработки в XVIII в. проблем эстетики, и, в частности, для Канта, традиция гедонизма и эпикуреизма угасла, Тэн это понятие сохраняет и с ним работает. 
В этом смысле показателен его панегирик вкусам древних греков, в которых нет ничего чрезмерного, возбуждающего, извращенного по сравнению с вкусами его, Тэна, века. «Мы с нашим притупленным, изнасилованным, привыкшим к крепким манерам вкусом готовы будем сначала назвать этот напиток пресным, - пишет он, используя метафору, - но, омачивая в нем губы в продолжение нескольких месяцев, мы не захотим больше пить ничего, кроме этой чистой и свежей воды, и найдем, что другие литературы не что иное, как кайенский перец, рагу или же отрава» [Тэн, 1933, c.243].

Или вот ситуация с упадком вкусов как следствия порчи нравов, жажды наживы и торжества мещанства в голландском искусстве XVII в. Страна становится слабой, герои превращаются в мещан. Национальный инстинкт слабеет. Искусство утрачивает национальные особенности, художники следуют моде, а мода уводит их из собственной страны. Жажда наживы и обогащения торжествует. Голландцы уже избегают дуэлей, драк и споров. Они стремятся к наслаждению. В их домах появляется роскошь. Они наполняются коврами, дорогими картинами, золотой и серебряной посудой. Армия уже неспособна сопротивляться. Образцы роскоши заимствуются из Франции и Италии. Рембрандт в 1669 г. умирает в бедности всеми заброшенный. А что же происходит со вкусами? Нет, Тэн об этом не забывает. Он пишет: «Одновременно с этим национальное чувство сказывается в искусстве с меньшей силой; вкус извращается...» [Тэн, 1933, с.199].

Вообще, в массовом обществе изменяются отношения между тем, что мы называем индивидуальным и коллективным. Это уже проблема, в том числе и для XIX в. Если индивидуальное содержание человека постигает психология, то коллективное - социология. Психология и приходит вместе с возникающим перевесом в массовых обществах коллективного, т.е. массового. Дело доходит до того, что некоторые состояния в поведении человека трудно отнести или просто к психологии, или просто к социологии. Тогда возникает еще одна наука на стыке - это социальная психология, изучающая поведение индивида в группе, в массе, в коллективе. И, конечно, рецепция искусства не может быть нейтральной по отношению к возникающим в XIX в. научным направлениям.

11. Взаимоотношения между социологией и историей искусства. Тэн как историкискусства

Называя Тэна социологом искусства и делая его как исследователя искусства репрезентативным по отношению к совершающемуся в XIX в. культурологическому повороту, нельзя упускать из вида, что становление социологии как науки в XIX в. только начиналось, а следовательно, первые попытки определить границы и предмет этой дисциплины не были еще столь совершенными. Но дело не только в этом. Хотя сам Тэн претендует на то, что направление, которое он в науке представляет, есть социология, правда, он называет это еще эстетикой или философией искусства, т.е. направлением, ставшим привычным после XVIII в., когда эти последние начали развиваться, все-таки за ним в последующей литературе закрепилось восприятие его метода как социологического. Здесь следует принять во внимание то обстоятельство, что, будучи социологом, Тэн, кроме всего прочего, в своих сочинениях предстает еще и историком искусства. Хотя он не претендует на универсальную историю 
искусства, как это имело место у И. Винкельмана, рассматривающего искусство не только греков, но этрусков, египтян, финикиян, персов и т.д. и сосредоточивает внимание на самых ярких страницах этой истории (греческое искусство, искусство Италии эпохи Ренессанса и т.д.), тем не менее, в его сочинениях улавливается некая универсальная схема истории искусства, по всей видимости, в самом общем виде заимствованная у Гегеля.

Таким образом, сопоставляя разные периоды истории искусства, Тэн предстает и не может не предстать здесь и историком искусства. А историческая наука в XIX в. тоже находится и в стадии зарождения, и в стадии становления. Тэн, несомненно, этот сдвиг ощущает. Об этом свидетельствует его суждение, которое мы извлекли из его книги о Тите Ливии. «Мы требуем еще от науки большей полноты. История обнимает теперь многие разряды фактов, которые доселе не входили в нее: механические ремесла, промышленность, торговля, бывшие в презрении у древних, как занятие рабов, ныне восстановлены в чести, потому что находятся в руках свободных людей; домашние нравы, некогда забываемые ради политических событий, ныне изучаются, потому что семья так же близко интересует человека, как и государство; религия, науки, литература, искусства, которые в то время представлялись делом нескольких личностей, - ныне считаются произведением всего народа. Расширенная область истории включила наконец в свои пределы всю человеческую природу» [Тэн, 1885, с.383].

В исторической науке на рубеже XVIII-XIX вв. происходит весьма заметная трансформация, что, конечно, не может пройти мимо внимания Тэна, не может не оказать на его сочинения об искусстве воздействия. Проблема в том, что в это время сложившиеся в сочинениях по истории, принадлежавших перу мыслителей Просвещения, представления об истории меняются под воздействием романтизма, а последний, как известно, был оппозицией по отношению к Просвещению, в том числе, и в том, что касается истории и науки об истории. Конечно, связь Тэна с тем историческим принципом, что положен в феноменологию Гегеля, имеется. А ведь Гегель представляет историческую мысль, какой она сложилась у просветителей. Конечно, пробуждение исторического знания - это заслуга Просвещения, но в его понимание романтики внесли столько нового, что кажется, что историю открыли не просветители, а именно романтики. Так, Х.Г. Гадамер констатирует происшедшую в XIX в. под воздействием романтизма переоценку ценностей, свойственную исторической науке. «Она (историческая наука. $-H . X$.), - пишет он, - уже не меряет прошедшее мерками современности, как неким абсолютным мерилом, но, напротив, признает за прошедшими временами их особое достоинство и готова даже согласиться с их превосходством в том или ином отношении. Великие свершения романтизма: пробуждение интереса к изначальным временам, вслушивание в голос народов, звучащий в песнях, собирание легенд и сказок, забота о старинных обычаях, открытие языка как мировоззрения, занятия «религией и мудростью индийцев» - все это вызвало к жизни и историческую науку, которая медленно, шаг за шагом, превратила полное предчувствий пробуждение в обстоятельное историческое познание» [Гадамер, 1988, с.327].

Может быть, границу между представлениями об исторической истине М. Фуко делает еще более резкой. Словно подтверждая сказанное Гадамером, М. Фуко 
в представлениях об истории в XIX в. тоже придает значение первоначалу, или «изначальным временам». Он пишет: «Таким образом, перед мыслью встает задача: подвергнуть сомнению первоначало вещей - для того, чтобы обосновать его вновь, обнаруживая при этом тот способ, благодаря которому строится сама возможность времени, то безначальное первоначало, на основе которого все и возникает. Задача эта предполагает, что сомнению подвергается все то, что принадлежит времени, образуется во времени, помещается в его подвижной стихии, а в результате выявляется тот вневременный, внеисторический разрыв, из которого проистекает и само время» [Фуко, 1977, с.426]. Это стремление принять во внимание в историческом знании первоначало чрезвычайно существенно в романтизме, а в символизме оно расцветает уже пышным цветом. Из символизма, как известно, выходят все авангардистские направления XX в., а они без тяготения к архаике, т.е. к тому же первоначалу в виде символических условных форм, вроде «геометрического стиля», просто не существуют.

То, что мы сейчас процитировали, принадлежит философам. А как эту тенденцию ощущают теоретики и историки искусства? Конечно, ощущают и принимают к сведению. Дело доходит до того, что в последние столетия в науке происходит тяготение к неживому, а следовательно, и к подъему наук о неживом (физике, химии, астрономии и т.д.). Сложившиеся в этих науках представления гуманитарные науки перенимают. Это касается не только науки, но и практики самого искусства. Об этом точно пишет Х. Зедльмайр. «И точно так же порыв к бессознательному, к доисторическому дает расцвет глубинной психологии, исследований первобытных народов, предыстории к ранней истории человека, истории жизни и земли, что сопровождается односторонними, но великими открытиями. Как в искусстве, так и в науке человека тянет к обнаружению мира, лежащего ниже всего живого, ниже человека, а внутри человека - ниже его дневной жизни. Стремление проникнуть в земные недра и глубины морей - побочный симптом подобного, куда более универсального прорыва» [Зедльмайр, 2008, с.157]. Не эту ли самую мысль можно вычитать из стихотворения О. Мандельштама 1932 г. «Ламарк»? «Если все живое лишь помарка // За короткий выморочный день, // На подвижной лестнице Ламарка // Я займу последнюю ступень. // К кольчецам спущусь и к усоногим, // Прошуршав средь ящериц и змей, // По упругим сходням, по излогам // Сокращусь, исчезну, как Протей // Роговую мантию надену, // От горячей крови откажусь, // Обрасту присосками и в пену // Океана завитком вопьюсь» [Мандельштам, 1991, с.177]. По сути, столь очевидный интерес к предметам, изучаемым Ламарком и Линнеем, можно обнаружить в символизме. Так, посвящая свою работу иконографии архитектуры европейского модерна, М. Нащекина констатирует наличие в этой иконографии форм биологической жизни, изображения простейших организмов или насекомых, например, моллюсков. «Бабочки, стрекозы, мотыльки - в виде оконных предметов, настенных росписей, рисунков кованых решеток или штукатурной декорации во множестве “разлетались” по европейским постройкам в стиле модерн» [Нащекина, 2006, с.164]. Стиль модерн культивировал проявления жизни низших организмов, обитателей подводного и подземного царства.

Но не тянется ли эта, столь характерная для XX в. тенденция, в XIX в., все к тому же позитивизму, к стремлению Тэна осмыслить опыт искусства, исходя из аналогии 
с растительным и животным миром. Обращаясь к трансформации исторического знания, на фоне которого конституируется социологическое знание об искусстве, во всяком случае, в лице Тэна в этой трансформации представлений об истории мы прежде всего пытаемся уловить и то, что для искусства специфично, т.е. его индивидуальное содержание. Это то, что Гегель сделал главным на романтической стадии становления духа. На этой стадии, как известно, дух уже тяготится выражением своего внутреннего содержания во внешних формах. Он уже самоценен. Это и выражает искусство в поздние эпохи. По мнению М. Фуко, происходящая на рубеже XVIII и XIX вв. трансформация - следствие появления на горизонте науки, но прежде всего в самой жизни той фигуры, которая в классической эпистеме отсутствовала. Под этой фигурой М. Фуко имеет в виду человека. В самом деле, называя предшествующий этап в науке классической наукой, М. Фуко отождествляет его с активностью естественных наук. А гуманитарные науки появляются лишь тогда, когда в поле зрения того, что М. Фуко называет эпистемой, появляется человек. Странное, однако, заявление. Но, может быть, не столько странное, сколько парадоксальное. Это обстоятельство и питает возникновение гуманитарных наук - новых, если они только возникают, и традиционных, если они в это время уже имели место.

Следующее суждение М. Фуко также не может не удивлять: «Странным образом, - пишет он, - человек, познание которого для неискушенного взгляда кажется самым древним исследованием со времен Сократа, есть, несомненно, не более чем некий разрыв в порядке вещей, во всяком случае, конфигурация, очерченная тем современным положением, которое он занял ныне в сфере знания. Отсюда произошли все химеры новых типов гуманизма, все упрощения “антропологии", понимаемой как общее, полупозитивистское, полуфилософское размышление о человеке. Тем не менее утешает и приносит глубокое успокоение мысль о том, что человек - всего лишь недавнее изобретение, образование, которому нет и двух веков, малый холмик в поле нашего знания и что он исчезнет, как только оно примет новую форму» [Фуко, 1977, с.41]. Но что у М. Фуко оказывается еще более парадоксальным, это то, что принцип историзма в XIX в. привел к тому, что историческое знание в своем развитии расщепилось на целый ряд частных историй. Видимо, это следует называть научным прогрессом. А следует ли? История уже вроде бы перестала быть историей человека. Историчность, пронизывающая человека, стала распространяться на самые разные сферы. Этот вывод не столь банален. Ведь это - исток амбивалентного отношения искусствоведа к методологии и теории. «Предполагается, - пишет М. Фуко, - что именно с этого момента (а Фуко имеет в виду XIX в. - H. X.) обнаруживающаяся в человеке историчность распространилась и на предметы, которые человек изготовил, язык, на котором он говорил, и далее на самое жизнь. Исследования экономики, история литератур или грамматики и, наконец, вся эволюция жизни кажутся лишь внешним результатом распространения на все более и более отдаленные участки познания той историчности, которая была открыта прежде всего в человеке» [Фуко, 1977, с.466].

Но ведь этот процесс увлекает и искусствознание. Оно стало более дифференцированным, но пока менее целостным. А что же может искусствознание вернуть к этой утраченной целостности, т.е. к образу человека в полноте его разнообразных проявлений? Казалось бы, если это так, то тут не является исключением и искус- 
ство. Его история тоже питалась и продолжает питаться представлениями о человеке, что имели место в классическую эпоху, т.е. до XIX в. Вот почему социология, психология и особенно семиотика так трудно прививаются к искусствознанию. Но вот парадокс. Оказывается, это расщепление истории на частные истории, на которых можно фиксировать печать истории человека, приводит к противоположному эффекту. Все это лишило человека его собственной истории («У человека нет больше истории: точнее, поскольку он говорит, трудится и живет, бытие его оказывается сплетением многих историй, которые ему чужды и неподвластны» [Фуко, 1977, с.467]. А ведь тут дело не в научном процессе, не в появлении новых методов исследования искусства, а в том, что приносит с собой цивилизация. Согласно М. Фуко, появившийся в начале XIX в. человек оказывается лишенным истории. Он становится неисторичным, а «время приходит к нему откуда-то извне, он становится объектом» [Фуко, 1977, с.467]. Объектом его делает цивилизация. Так ведь это уже знали социологи XIX в. Знал Э. Дюркгейм, которого мы уже цитировали, и знал Тэн.

Но если человек превратился в объект, то какие следствия для исторической науки отсюда вытекают? Видимо, значительные, а именно: вся эта дифференциация исторической науки на разные частные истории позволяет прийти к выводу о том, что человек как таковой зависит от самых разных обстоятельств и стихий. И вот окончательный и отнюдь не пессимистический вывод М. Фуко, который, как может показаться, продемонстрировал, как появление на горизонте истории человека в эпоху новой эпистемы одновременно оказалось и его исчезновением. Да, в какой-то степени так оно и было, так оно и есть. Но это следует понимать так, что в XIX в. был открыт не вообще человек, как это имело место в XVIII в., а человек, каким он предстал на том этапе истории общества или, еще точнее, цивилизации, который есть XIX в., когда мыслители ощутили кризис гуманизма. А еще точнее, в тот момент, когда развертывается следующая волна в переходе от культуры одного типа к другому. Иначе говоря, в этот момент был, собственно, открыт не человек, а его образ, точнее, один из его образов, тот образ, что соотносим с культурой чувственного типа. Тот образ, что в этом столетии в силу складывающихся обстоятельств возникает.

Когда Тэн пытается понять зависимость искусства от среды и момента, то этот момент в его время следует понимать как момент переходный. Это как раз и есть то, что Тэн подразумевает под сознанием общества, его нравов, воззрений и вкусов. Несмотря на фрагментарность этого образа, который пытаются осмыслить разные науки, все же в конечном счете, благодаря новой историчности, создается и некое целостное представление о человеке. Только оно не сразу оформилось. А окончательно оно оформится лишь в культурологической рефлексии. Дифференциация наук о человеке порождает потребность в интеграции, что и произойдет по мере возрастания внимания к культуре. И тогда многочисленные признаки социума, которые делает предметом исследования Тэн, будь то среда, состояние нравов и т.д., предстанут элементами целостной системы, которая и есть культура. «Так сквозь историю позитивностей проступает более глубокая история самого человека, - пишет М. Фуко. История эта относится к самому его бытию: он обнаруживает, что не только где-то вокруг него существует “некая история”, но что сам он в своей историчности и есть 
то, в чем прорисовывается история человеческой жизни, история экономики, история языков. Таким образом, на некоем глубинном уровне существует историчность человека, которая есть одновременно и история его самого, и то перворассеяние, которое служит обоснованием всех других историй» [Фуко, 1977, с.468].

Иначе говоря, дифференциация наук о человеке - не результат, а процесс, движение к обретению синтеза, а точнее, целостности. Но такое видение человека даст лишь культурология, в которой все остальные науки, в том числе и социология, оказываются включенными в систему. Иначе говоря, эта целостность человека предстанет в новом варианте, а этот вариант будет следствием возрождающегося типа альтернативной культуры. Спрашивается, если XIX в. с его новой историчностью снова собирает в человеке и через человека все возможные и многочисленные частные истории самых разных явлений и сфер, то тем самым не покидаем ли мы уже то, что привычно связываем с социологией, и не оказываемся ли мы уже в пространстве культуры? Более того, в пространстве альтернативной культуры. И не обещает ли то, что мы называем социологическим поворотом, уже поворот культурологический? Ведь, собственно, культура и является тем основанием, на котором только и возможен синтез разнородных сфер, каждая из которых претендует на частную историю. Но синтез, развертывающийся в альтернативной культуре, будет уже другим. И не прорвались ли мы в связи с возникновением новой историчности на территорию уже другой науки? Человек на этой территории оказывается включенным в самые разные связи и отношения, которых оказывается значительное количество, что и приводит к ощущению, что образ человека в этих связях и отношениях исчезает.

Вот именно это и пугает искусствоведа, которому кажется, что приложение к искусству методов новых наук предстает самым настоящим жертвоприношением. Жертвой, как они полагают, является человек. Да, конечно, в новую эпоху человек предстает, в том числе, и жертвой. Только жертвой его делает цивилизация. Это, разумеется, не может не пугать искусствоведа, не готового к тому, чтобы жертвовать тем, к чему он привык, - индивидуальным смыслом, хранителем которого является лишь искусство. Вот и объяснение того, почему новая историчность, питавшая историю искусства на ее ранних этапах, а именно в XIX в., потеснила «жизнеописания» художников, т.е. «имен», которыми занимался Д. Вазари, и обязывала искать закономерности, в зависимости от которых в поздней истории оказывается человек.

\section{2. Ориентация на социальное и ориентация}

на индивидуальное в истории цивилизации:

о т социологи и к п ихологии

Поставим следующий вопрос: не ускользает ли от исследователя то индивидуальное содержание, которое в произведении имеется? Социолога интересуют факты, а факт - это, с точки зрения социолога, вещь коллективная, массовая, а следовательно, постижимая в форме статистики, получаемой в результате эмпирических опросов. Индивидуальные смыслы произведения нейтрализуются не только в творческом процессе, но и в процессе постижения произведения публикой. Таким образом, социология искусства может предстать социологией функционирования искусства как института, осуществляющего определенные социальные функции. Собственно, институциональный подход был вызван к жизни уже в период первой волны ста- 
новления социологического знания, т.е. в XIX в. и с той поры не пересматривался. Так, соотечественник и современник Тэна Э. Дюркгейм, один из пионеров французской социологической школы, формулировал: «Как было ранее отмечено, есть слово, которое, если несколько расширить его обычное значение, довольно хорошо выражает этот специальный способ бытия; это слово “институт”. В самом деле, не искажая смысла этого выражения, можно назвать институтом все верования, все поведения, установленные группой. Социологию тогда можно определить как науку об институтах, их генезисе и функционировании» [Дюркгейм, 1995, с.20]. Но Э. Дюркгейм уже близок к более современному функциональному подходу в социологии. Вот, например, как он определяет функцию, в том числе и социального института. Э. Дюркгейм различает порождающую социальное явление причину и осуществляемую им функцию. «Мы предпочитаем пользоваться словом “функция”, а не “цель” или "намерение" именно потому, что социальное явление обычно не существует для достижения полезных результатов, к которым они приводят. Нужно определить, имеется ли соответствие между рассматриваемым фактом и общими потребностями социального организма, в чем состоит это соответствие, не заботясь о том, чтобы узнать, преднамеренно оно возникло или нет. Все вопросы, связанные с намерениями, слишком субъективны, чтобы можно было рассматривать их научно» [Дюркгейм, 1995, с.112].

Так, что отцы-основатели новой науки - социологии - уже в XIX в. поставили вопрос и об институциональном и функциональном подходах к социальным явлениям [Художественная..., 1986]. Ведь лишь применяемые к искусству, эти подходы позволяют утверждать, что в исследовании искусства возникает новая парадигма, для которой предметом будет искусство как социальный институт, осуществляющий в обществе целый ряд специфических функций. Однако что означают институциональный и функциональный подходы как подходы позитивистские и, следовательно, социологические? А то, что если искусствоведу подчас трудно дать определение, что такое искусство, какова его природа и предназначение, то социолог помогает ему это уяснить, обращая внимание на функции искусства. Если мы имеем информацию о функциях искусства, то нам уже легче объяснить, что такое искусство и для чего оно вообще существует. Однако речь идет не вообще о функциях, а о социальных функциях. Это означает, что знание о таких функциях предполагает знание об обществе. Какое общество, такое и искусство. Но только знание о функциях раз и навсегда не дается. Общество - это такая реальность, которая весьма динамична. Оно проходит разные этапы. А следовательно, каждый этап может рождать новые потребности общества. Но новые потребности требуют и новых функций социального института [Хренов, 2019].

О каких-то функциях нам известно давно, и они могут сохраняться на протяжении длительного периода. О каких-то нам неизвестно. Поэтому социологи кроме явных функций выделяют функции латентные. Чтобы выявить их, необходимо проводить эмпирические опросы. Отмеченное нами достоинство научного исследования искусства с помощью социологии имеет, как мы стараемся показать, и обратную сторону. Обнаруживая в сфере искусства дотоле необъясненные аспекты его функционирования, мы в то же время жертвуем тем субъективным, тем индивидуальным, что в искусстве является самым главным и самым важным. Но в то же время 
и способным ускользать в результате наделения искусства самыми разными функциями. Прирост знания об искусстве, оказывается, еще не приближает к его сущности и, может быть, от него даже удаляет. Вот почему в сообществе искусствоведов всегда существовало и продолжает существовать не только стремление овладевать новой методологией, но в то же время и опасение, что всякая новая методология способна не только приблизить к тому уникальному, что в искусстве есть, но и отдалять от него. Удалять от эстетического смысла искусства.

Опасения вполне естественные. Как же их преодолевать? Видимо, существует лишь один выход - восполнять утрату уникального, утрачиваемого при одном подходе обращением к другим наукам. В самом деле, некоторый упадок интереса к социологии со стороны научного сообщества и со стороны искусствоведов к концу XIX в. объясняется успехами возникшего в этом столетии интереса к психологии, что, как нам представляется, можно объяснить способностью этой науки вернуть искусству то уникальное, что, как кажется, утрачивалось при использовании социологического подхода. Следует отметить, что Тэн не прошел мимо поворота в сторону психологии, хотя его коллеги по цеху, например тот же Э. Дюркгейм, этого не допускали. Проблема лишь в том, а не изменяет ли Тэн в случае обращения к психологии тому методу, который им избран и главным последователем которого в XIX в. он был, как это и считают некоторые его почитатели. Скажем, один из самых авторитетных представителей социологического сообщества Э. Дюркгейм весьма категорично высказывался против альянса между социологией и психологией. Для него психологизм был явным и скрытым препятствием на пути становления социологии как самостоятельной науки [Гофман, 1995, с.321].

Но что касается Тэна и его отношения к психологии, то он такого жесткого разведения социологии и психологии избегал. Это и понятно. Его как искусствоведа притягивало к психологии именно индивидуальное начало, без которого искусство не существует. Наоборот, уклон в сторону психологии, который в сочинениях Тэна имеет место, как раз и позволяет ему быть, несмотря ни на что, современным до сих пор. Именно это констатирует и Ш. Лало: «Итак, в эстетических воззрениях Тэна индивидуальность отнюдь не отсутствует, как это слишком часто утверждали: подобный пробел разрушил бы его систему. Но пробел этот может быть заполнен лишь новым методом, наиболее бросающаяся черта которого состоит в преобладании дедукции над индукцией, а наиболее существенное - в том, что он касается внутренних условий творчества, тогда как объяснение условиями среды является внешним по отношению к изучаемому явлению» [Лало, 1915, с.192].

Нам сейчас важно поставить вопрос о соотношении индивидуального и массового начал в методе Тэна, как и вообще в науке, но в самой реальности. Ведь это в самом обществе, сквозь призму которого Тэн пытается осмыслить художника и его произведение, устанавливается это самое различие между индивидуальным и социальным, т.е. массовым. В этом смысле заслуживает внимания идея, высказанная теми мыслителями XIX в., которые вызвали к жизни тот предмет изучения социологии, который они называют «цивилизацией». Тот поворот, что в XIX в. происходит в восприятии общества, которое с некоторых пор предстало синонимом цивилизации, давал и некоторую надежду на то, что при социологическом подходе не может утрачиваться и то уникальное и индивидуальное, что является в искус- 
стве самым ценным. Дело в том, что цивилизация предполагает культивирование не только коллективных, но и индивидуальных ценностей. В связи с этим процитируем историка - представителя знаменитой исторической школы «Анналы» Л. Февра, который сам приводит цитату из теоретика и историка цивилизации Франсуа Гизо, называя ее «прекрасной».

Нам тоже хочется вслед за Л. Февром суждение Ф. Гизо назвать весьма конструктивным. Что же такое в процитированном суждении Л. Февра так восхитило? Пожалуй, вслед за Л. Февром такую оценку можно повторить, ведь она позволяет, как нам представляется, разрешить противоречие, связанное с социологическим подходом по отношению к искусству. «Любопытно отметить, что он (Гизо. $-H$. $X$.) тут же добавляет: Л. Февр пишет: даже такие явления, которые, собственно говоря, нельзя назвать социальными, - индивидуальные явления, которые, казалось бы, более относятся к человеческой душе, чем к общественной жизни, - таковы религиозные верования и философские идеи, науки, литература и искусства», - они тоже могут и должны рассматриваться «с точки зрения цивилизации» [Февр, 1991, с.272]. Но это, так сказать, идеальная ситуация, а о чем же говорит реальность? Согласно Ф. Гизо, цивилизация включает в себя уровень и социального, и, с другой стороны, интеллектуального развития. «С одной стороны, есть развитие условий, внешних по отношению к человеку и всеобщих; с другой - развитие внутренней и личной природы человека; одним словом, есть совершенствование общества и таковое же аспектов человеческих» [Февр, 1991, с.273]. При этом здесь имеется в виду даже не синтез этих уровней, а их взаимное воздействие в процессе развития цивилизации. Так сказать, гармония. Однако в реальности какой-то из этих уровней способен опережать другой. Социальный прогресс может не сопровождаться прогрессом интеллектуального развития.

Спрашивается, является ли такой прогресс цивилизации жизнеспособным? Но ведь не является эффективным и первый вариант. В этом случае, конечно, следует привести примеры. Так, например, по мысли Ф. Гизо, английская цивилизация демонстрирует лидерство социального уровня. Но противоположный уровень здесь свидетельствует о том, что ее гении оказались лишенными таланта «зажечь мощные факелы разума, которые осветили бы целую эпоху». Иное дело - немецкая цивилизация, она является мощной в духовном смысле и одновременно демонстрирует слабость в социальном совершенствовании. Однако Ф. Гизо известна и цивилизация, в которой эти два уровня достигли гармонии. По его мнению, это Франция.

Нас это противопоставление социального и индивидуального интересует в связи с тем, что Тэн уже не только как социолог, но и как историк подразумевает под расцветом и упадком искусства два сменяющих друг друга периода и в истории постоянно повторяющихся. Разве расцвет искусства нельзя объяснить тем, когда индивидуальная стихия в цивилизации возникает и расширяется, не наталкиваясь на барьеры, которые существуют в обществе? Разве не объясняется упадок тем, что эта индивидуальная стихия начинает сдерживаться, вводиться в определенные границы, а то и просто вытесняться на периферию. Допустим, что в реальности и в самом деле можно отыскать самые разные типы коммуникации между социальным и индивидуальным, пусть эти два понятия могут иметь синонимы. Скажем, социальное употребляется как синоним коллективного, а индивидуальное - как си- 
ноним духовного и т.д. В конечном счете нас будет интересовать судьба индивидуального, поскольку нашим предметом является искусство и тот метод, который в XIX в. предложен для его изучения. Но как же в этом случае поступать социологу? Должен ли он ставить акцент на социальном начале, превращая его в предмет своей науки или он в этот предмет включает и индивидуальное начало? А может быть, индивидуальное начало, коль скоро оно так важно для понимания цивилизации, требует уже другой науки.

Да, другой - мог бы ответить на этот вопрос категоричный в этом смысле Э. Дюркгейм. Он склонен к тому, чтобы провести четкую границу между социальным и индивидуальным, как и между науками, изучающими эти предметы. К нему можно было бы прислушаться. Так, он убежден, что социология призвана изучать лишь социальные факты. Что касается психологии, то ее предмет связан с индивидуальными проявлениями человеческого бытия. Э. Дюркгейм утверждает первостепенность социальной реальности по отношению к реальности индивидуальной. Реальность социальная - это не простая сумма составляющих общество индивидов. Это принципиально новая реальность. Однажды возникнув, она начинает функционировать по своим собственным законам, которые могут затруднять востребованность художника. Поэтому она имеет исключительное значение для детерминизма индивидуального поведения. В данном случае индивидуальная реальность по отношению к социальной является вторичной. Процитируем по этому поводу вывод А. Гофмана, когда он констатирует жесткость разделения этих двух реальностей, в которой недвусмысленно формулируется суть социологизма. По Э. Дюркгейму, социальные, т.е. коллективные, представления господствуют над индивидуальными, а коллективное сознание - над индивидуальным. «Социальные факты, по Дюркгейму, обладают двумя характерными признаками: внешним существованием и принудительной силой по отношению к индивидам. Общество в его интерпретации выступает как независимая от индивидов, вне- и надындивидуальная реальность. Она - «реальный» объект всех религиозных и гражданских культов. Оно представляет собой более богатую и более «реальную» реальность, чем индивид; оно доминирует над ним и создает его, являясь источником всех высших ценностей» [Гофман, 1995, с.318].

Конечно, эта индивидуальная реальность, как для Дюркгейма - реальность, вторичная по отношению к социальной, также заслуживает внимания науки, только науки другой, а именно психологии, той самой системы рефлексии, мимо которой Тэн как представитель науки о человеке пройти не может. Его суждения психологического характера имеют такую же ценность, как и суждения социологического характера. Только вот при этом он не затрагивает, в отличие от Дюркгейма, методологических тонкостей. Он просто вынужден постоянно выходить к обсуждению психологических проблем искусства, ибо его предмет - искусство - понять без этого аспекта невозможно. В связи с этим отделением социального от индивидуального, а социологического от психологического закономерен вопрос: раз общество соотносится с надындивидуальной реальностью, раз оно способно ограничивать индивидуальные проявления воздействовать на сознание человека и его поведение жестко определять, то не выступает ли оно часто тем средством, которое способствует не только расцвету искусства, но и его упадку, сдерживая индивидуальную стихию, 
а следовательно, и художественное вдохновение? Этот вопрос кажется почти риторическим, особенно для нас, людей XXI в., ставших очевидцами и даже жертвами тоталитарного режима. Хотя этот вопрос является риторическим, и для Тэна, пытавшегося разгадать ту оттепель, которая в истории нередко посещала тот или иной народ, это было совершенно очевидным. Поэтому, имея в виду общество, он и прибегает к понятию «машины» как созданной самим человеком, но способной функционировать, нанося своему создателю вред. Мысль эта, конечно, в последующей истории будет не раз повторяться. Ее повторит, например, другой французский мыслитель - А. Бергсон.

\section{3. Формула «история искусства без имен»} как выражение духа позитивизма в ситуации нар аст ющей индивидуализаци и скус ства

Для нас вопрос, связанный с соотношением коллективного и индивидуального, особенно важен. Ведь сверхзадачей нашей работы является нахождение аргументов по поводу усложнения и совершенствования методов исследования искусства, позволяющих дать более глубокое истолкование искусства. При этом будем исходить из того, что искусство в его поздних проявлениях является выражением преимущественно индивидуального духа. Однако необходимость существовать в границах цивилизации связана с возникновением его новых функций, а главное - с повышением в нем того, что является уже коллективным. В этом смысле и XVIII, и XIX в., когда возникают новые науки, особенно проблемны. Ведь с появлением новых наук возникают и новые возможности для анализа искусства. В чем же проявляется их новизна? Какие именно смыслы искусства помогают эти новые науки выявить? Когда мы говорим «искусство», то это понятие предполагает наличие в нем индивидуального смысла. Того смысла, который, может быть, во всей его сложности и полноте выражает лишь художественная деятельность. Так позволяют ли новые науки, когда мы переносим их методы в сферу искусства, глубже проникнуть в индивидуальную стихию искусства, которая, как нами уже отмечено, в последние столетия, кажется, не ослабевает, а, наоборот, усиливается? Но происходит ли это, и если происходит, то в чем это проявляется? Позволяет ли, в частности, применяемый Тэном метод это продемонстрировать?

Позволяет ли вообще метод Тэна утверждать, что тот социологический поворот, что первый раз произошел в XIX в. и, следовательно, предвосхитил культурологический поворот, давать исчерпывающую интерпретацию искусства, способствовать более глубокому проникновению в его сущность? Ответить на все эти вопросы не так-то просто. Ведь, по сути, и у Тэна, и не только у Тэна можно вычитать то, что, кажется, может получить на все эти вопросы лишь отрицательный ответ. В самом деле, вернем известный по Г. Вельфлину искусствоведческий тезис «история искусства без имен» к его философскому, т.е. гегелевскому, происхождению. Гегель не то чтобы отверг «имена», он просто их отодвинул и на первое место в истории искусства поставил состояния духа. Правда, великий мыслитель однажды высказал и весьма неосторожный, и в общем ошибочный вывод о возможности исчезновения и, еще точнее, смерти искусства. Это не значит, что Гегель заменил имена состояниями духа. Но у него эти «имена» оказываются значимыми каждый раз лишь в том 
случае, если они выражают эти состояния духа. Те же художники, которые этим состояниям не соответствуют, просто оказываются невостребованными и неосуществившимися.

Но разве не продолжают этот вопрос по-прежнему решать и современные историки искусства? Разве Х. Зедльмайр не возвращает к мысли, что методология истории искусства в ее втором смысле, т.е. выступающая как искусство углубленной интерпретации конкретных произведений искусства, все еще несовершенна и продолжает быть проблематичной? Разве не прав был Ф. Ницше, когда он находил у Тэна гегелевские идеи? Ведь и в самом деле тэновское определение, которое в его сочинениях предстает в разных вариантах, вроде бы не повторяет Гегеля. Тэн не употребляет понятие «дух», но он постоянно говорит о состояниях общества, социальной среде, нравах и воззрениях общества и т.д. Разве это не та же самая гегелевская идея об истории искусства без «имен»? Она изложена на философском, а точнее, позитивистском языке, т.е. языке, более близком XIX в., в котором новые науки, выходящие из философии, подчеркивают свою независимость по отношению к философии. И как бы ни сопротивлялся лидер социологии XIX в. Э. Дюркгейм использованию философских представлений в социологии, стремясь утвердить самостоятельность социологии как науки, тэновская теория это подтверждает.

Ну, а теперь по поводу того, как же быть все же с «индивидуализмом», неповторимостью каждого факта искусства, что, может быть, самое в нем главное, за что мы его ценим и что не позволяет ему, вопреки гегелевскому прогнозу, умереть. Как совместить индивидуальное и неповторимое с состояниями социальной среды, которые Тэн сделал предметом анализа, а следовательно, с коллективным и повторяемым, поскольку ведь социальное - это и есть коллективное, и есть массовое, что без статистики, а значит, и социологии уже не осмыслить. Собственно, именно это мы и делаем предметом нашего исследования, обращаясь к разным вариантам рефлексии об искусстве, имеющим место в истории, и, в частности, к тому варианту, что стал репрезентативным для теории, философии и истории искусства в ситуации имеющего место в XIX в. социологического поворота в науке. Как быть, однако, с тем, что открыли позитивисты, т.е. в чем состоит сущность социологического поворота? Ведь, по сути, этот поворот привел к открытию цивилизации, но не культуры.

А что же дает социология культуре и способна ли она объяснить что-то в культуре, а если способна, то что именно? А. Кребер в своем сочинении проронил одну мысль, которую не расшифровал. Он говорит: культура является осознанным феноменом лишь отчасти [Кребер, 2004, с.18]. Это очень точно. Эта неполная осознанность культуры, несмотря даже на использование позитивистского подхода, требующего предельной ясности, совершенно очевидна. Ведь в каждом типе культуры продолжают быть реальными, но неосознаваемыми элементы альтернативной культуры. Вот как можно расшифровать суждение А. Кребера. Не открыли ли позитивисты то, что сами не могли до конца объяснить и что позднее попробуют объяснить О. Шпенглер и П. Сорокин? Позитивисты, как мы уже показали, открыли цивилизацию. Но что есть цивилизация и как они ее поняли? Есть ли цивилизация - синоним культуры, т.е., по сути, одно и то же, или же она входит составной частью в культуру? А может быть, такой частью она не является, претендуя на самостоятельность? 
Можно ведь посмотреть на цивилизацию и так. Только в какую именно культуру? Может быть, как раз в ту культуру, которая является реальностью лишь XIX в.

Попробуем реальность культуры пока отождествить с XIX в. А что значит реальность культуры ХІХ в.? Что это за мгновение в истории человечества, ну пусть не человечества, а только Запада? Скорее это не вся культура, точнее, не вся культура в ее длительности, а лишь один из ее циклов или периодов, который определяет О. Шпенглер. По О. Шпенглеру, ХІХ в. входит в тот период истории западной культуры, который начинается где-то в конце XVIII в. и будет иметь продолжение в XX в. Этот период им назван периодом цивилизации в истории западной культуры. Проблема лишь в том, что, по О. Шпенглеру, это финальный период в истории западной цивилизации. Это тот период, который обязательно проходит каждая цивилизация и который он вслед за Ф. Ницше находит в античной цивилизации. Если так посмотреть на дело, то получается, что связывать понятие цивилизации с прогрессом, как это делали позитивисты XIX в. в лице Бокля и Гизо, уже не приходится.

Возможно, позитивисты не поняли, что они открыли. Это не случайно. Открытое ими они не мыслили в соответствии с историзмом. Но не вообще с историзмом, а со специфическим историзмом, который понятен, если будут осмыслены специфические ритмы развития и функционирования культуры. Более того, если принимать во внимание это «вечное возвращение», т.е. смену разных типов культуры. И это совершенно понятно: ведь они выражают дух предельно рационалистического и логоцентрического типа культуры - культуры чувственного типа. Они - охранители и выразители именно этого типа культуры. Ими осознана и осмыслена культура именно этого типа, а с ее помощью и вообще культура. Но в бессознательном культуры сохранились еще уровни альтернативной культуры, которые по отношению к искусству не являются нейтральными. Для позитивистов все, что существует вне границ этого типа культуры, не существует. Они этого просто не видят и размышлять об этом не могут. Но это все-таки существует. По крайней мере, в тех же самых эстетических и художественных формах.

Любопытно в связи с этим отметить, что, проникая в историческую науку, социологию и культурологию, идея «истории без имен» возникает именно на том этапе истории становления духа, который Гегель связывал с интенсивной индивидуализацией, с взрывом внутреннего содержания, который уже невозможно передать, лишь прибегая к внешним формам выражения. Этот этап Гегель называл романтическим этапом в истории духа, отождествляемого им не со стилем и мировосприятием романтизма, а вообще с историей христианства с момента его возникновения. Здесь невозможно не отметить противоречия. Искусство все больше углубляется во внутреннее содержание, а методология его изучения, приходя из смежных и новых наук, как кажется, все больше удаляется от индивидуализированного и внутреннего. Это касается прежде всего социологии и культурологии. Особенно в том случае, когда эти рождающиеся науки стремятся заимствовать методы естественных наук.

Ведь что, собственно, предстает предметом внимания у исследователя искусства, когда он искусство соотносит со средой, т.е. с обществом? А то, что ему приходится расширять поле своего внимания за счет необходимости давать характеристику уже не только искусства, но и общества. Раз Тэна интересуют состояния нравов и воззрений общества, то, следовательно, нужна характеристика самого общества, 
находящегося на определенном этапе своего развития. Эти характеристики общества у Тэна начинают превращаться в очерки большого объема, что не могли не отмечать первые рецензенты его книг. Так, откликаясь на очерк о живописи Ренессанса, включенного в «Философию искусства» Тэна, В. Герье пишет: «В очерке Тэна речь идет гораздо менее о самом искусстве, чем об окружавшей его среде; исследователь более занят описанием быта и условий, среди которых возникло взятое им явление, чем характеристикой самого явления, и можно сказать, что очерк Тэна имеет более значения для истории культуры, чем для истории искусства» [Герье, 1889, с.91]. Как же Тэн этот недостаток, возникающий в силу его приверженности к избранному методу, преодолевает? А так, несмотря на прокламированную верность провозглашаемого метода, Тэн остается искусствоведом, т.е. он чувствует субъективное и индивидуальное начало искусства. Но нет ли в этом противоречия в методе Тэна? «Наконец, нужно заметить, - пишет В. Герье, - что если, тем не менее, формула Тэна дала в его очерке блестящий результат, то это потому, что она восполнялась талантом Тэна, меткостью его наблюдений, выразительностью и образностью его слога. Эта оговорка применима и ко всем прочим приемам и способам исследования Тэна. Его метод неразлучен со свойствами и особенностями его таланта и - можно даже сказать - приноровлен к его таланту. Орудие, как Тэн называет свой метод, часто действует успешно лишь потому, что им руководят глаз и рука изобретателя, и иногда может казаться, что и весь метод - не что иное, как теоретическое оправдание присущего Тэну таланта характеризовать и живописать» [Герье, 1889, с.91].

Таким образом, ведь что у рецензента Тэна получается? А получается то, что не только в предмете, т.е. в обществе, метод Тэна выявляет индивидуальное начало, но и в самом исследователе как представителе гуманитарной науки рецензент это индивидуальное начало выявляет. Как бы Тэн ни формулировал зависимость гуманитарного знания, а следовательно, и его собственного подхода к искусству от естественных наук, исключающих это индивидуальное начало, все равно в его сочинениях это индивидуальное начало выходит на первый план. Это идет не только от его личных предпочтений, но и от предмета, который он анализирует. Замечание В. Герье все же является справедливым. В сочинениях Тэна, посвященных искусству, больше информации об обществе, нежели о самом произведении. И если речь у него идет о произведении, то в нем он видит исключительно проекцию тех процессов, которые для него являются значимыми. Но означает ли это, что такой анализ произведения является исчерпывающим? В этом смысле стоит прислушаться к Н. Страхову, который в XIX в. и переводил его сочинения, и писал о нем. Так, отдавая должное таланту Тэна, он замечает: «Но нельзя не признать, что эти писания оставляют в нас, однако же, какую-то неудовлетворенность. Мы чувствуем, что они не подымаются до высшей оценки произведений поэзии и искусства и потому не возбуждают и не воспринимают в нас любви к этим произведениям. Каждого поэта и художника автор разлагает на его элементы и показывает нам происхождение этих элементов. Можно подумать, что произведение художества происходит как непроизвольное сочетание особенностей народа, страны, вкусов, нравов и обычаев данного времени. В чем состоит цельность художественного произведения, его неисчерпаемая жизненность и то его главное качество, по которому оно бывает нам дорого, какому бы 
веку и какой бы стране оно ни принадлежало, - этого нельзя понять по изложению» [Страхов, 1893, с.248].

Все это так, и невозможно пройти мимо того, что Тэн следует парадигме Кювье и Ламарка, т.е. понимает историю как историю природы, в том числе и историю природного в самом человеке. Но ведь и сама историческая наука, если ее рассматривать именно в форме XVIII и XIX в., не стоит на месте. Именно в это время она радикально изменяется. В новой парадигме, что начинается с конца XVIII в., история приобретает уже не природное, а человеческое измерение. Представления, складывающиеся в границах классического знания, т.е. с начала XVII в., конечно, еще не уходят в прошлое, но они уже вытесняются тем, что М. Фуко назовет новой и, еще точнее, современной эпистемой. В этой парадигме история трансформируется в историю человека, переставая быть историей природы. М. Фуко, может быть, и преувеличивает, утверждая, что до появления современной эпистемы человек не существовал. Он, конечно, существовал, но история не видела еще самого главного в человеке - его не природного, а духовного содержания. С конца XVIII в. человек для историка появляется уже в новом образе, следствием чего, конечно, и является возникновение целой группы новых наук, которые будут называть гуманитарными. Это, кроме эстетики, история искусства, теория искусства, филология, социология, психология, критика, поэтика и т.д.

По сути, новое представление об историчности как значимое следствие включения в историю таких проявлений человека, которые ранее на себя внимание не обращали (например, бессознательного), сделало возможным появление науки об искусстве. Тэн как один из первых мыслителей попытался воспользоваться возникшей перспективой в науках об искусстве. Было бы странным, если бы его рефлексия была свободной от противоречий. В этой его рефлексии можно уловить и инерцию, т.е. провозглашаемую зависимость от методологии естественных наук, от Линнея и Ламарка, и в то же время интуитивное постижение нового историзма с человеческим содержанием, позволяющим в анализируемых фактах искусства уже улавливать ту истину о человеке, которая до XIX в. оставалась неизвестной. Но интерес к рождающемуся методу постижения искусства, естественно, был характерен не для одного только Тэна. Просто он оказался самым известным исследователем, выразившим установки эпохи.

Что же в конце концов является предметом постижения Тэном, когда он обращается к искусству? Хотя Тэн - исследователь, которого привлекали и другие сферы. Например, он - автор истории Французской революции в нескольких томах [Тэн, 1907]. Поскольку же Тэн считается социологом и поскольку научные установки времени способствовали его увлечению позитивизмом, то понятно, что предметом его исследования является не только и не столько искусство как таковое, а то в искусстве, что проецируется в него обществом. Но ведь то, что стоит за обществом, следует расшифровать. В XVIII в. социальная мысль уже пробуждается, достигая в иных случаях вершин (Вико, Монтескье, Вольтер, Руссо, Дидро и т.д.). В этот период рождается общество нового типа, которому в истории следует найти место, точнее, понять, в каком историческом моменте находится в XIX в. западное общество. А ответ на этот вопрос возможен лишь в том случае, если западное обще- 
ство сравнить с другими, на него непохожими обществами, которые когда-то были, но угасли, а также и с теми, которые существуют одновременно с Западом.

Хотя последующая мысль будет еще долго на этот вопрос отвечать, Тэн находится в самом начале таких ответов. Потому в своих сочинениях он сопоставляет разные народы и разные культуры. Осмысляя влияние общества на искусство античности, он постоянно возвращается к современному ему обществу. Такие же сопоставления у него современного ему общества с итальянским обществом XV-XVI вв. Ведь, по сути, у Тэна рождается уже рефлексия, которая позднее в совершенном виде предстанет у Шпенглера. В конце концов и сам Шпенглер еще не свободен от позитивизма, рассматривая культуры как биологические организмы, проходящие в своем развитии самые разные фазы. Фиксируя у Тэна противоречие, - с одной стороны, использование метода Кювье, т.е. понимание истории как истории природы и животного мира и перенос ее закономерности на человеческую историю, а с другой, пытаясь постичь специфические закономерности этой самой человеческой истории как специфические и несхожие с закономерностями в истории природы, мы можем сказать, что противоречие Тэна - это не его личное противоречие как исследователя. На его рефлексии лежит печать становления науки. В XIX в. эта самая наука находится еще в стадии перехода к новой парадигме.

Теперь несколько заключительных суждений относительно понимания предмета исследования Тэна, т.е. того, чем общество способно наделять в разные эпохи своей истории искусство. Сопоставляя разные эпохи и культуры, Тэн пытается в них выявить разные состояния и прежде всего - состояния духовного подъема и духовного упадка или декаданса. Когда он описывает эпохи подъема и сопоставляет их с XIX в., он, по сути, относится к современности как к цивилизации в понимании Шпенглера. Для него античность и Ренессанс - идеал, а современность - это декаданс. Когда же он описывает эпохи упадка, он пытается осмыслить их по принципу зеркала. Декаданс в истории античной и ренессансной культуры позволяет лучше и глубже проанализировать тот декаданс, который в XIX в. ощущал не только Тэн, но уже Шопенгауэр и Ницше. Осмыслив противоречие в рефлексии не только Тэна, но и в науке его времени, мы перейдем к следующему вопросу, а именно: что дает новая эпистема, следствием которой явилось появление новых наук, а именно наук гуманитарных, познанию искусства?

И тут в отношении к новой методологии следует фиксировать некоторую амбивалентность. С одной стороны, научная революция, в особенности проявившаяся в гуманитарных и социальных науках, восхищала и привлекала, провоцировала ученых обращаться к искусству. Ведь не один же Тэн пытался в соответствии с новыми подходами осмыслить искусство. Свои размышления об искусстве осваивали все более или менее выдающиеся сторонники позитивизма - Спенсер, Милль и т.д. Но даже если не все из них пытались перенести свои представления в сторону искусства, то этим воспользовались другие. В этом смысле интересна попытка К. Леонтьева предложить и аргументировать периодизацию культуры, опираясь на открытия Спенсера, о чем мы уже говорили. Казалось, что новая методология позволяет открыть и объяснить грани и возможности искусства, до сих пор не получавшие объяснения. Это, действительно, так, поскольку понижение интереса, например, к социологии в связи с появлением психологии к концу XIX в. не было окончательным. 
Интерес к социологическому исследованию искусства снова вспыхнул в 20-е гг. [Фриче, 1926а, с.3-17; Фриче, 1926б; Шмит, 1927; Гаузенштейн, 1924], а затем и в 60 -е гг. ХХ в. Возникнув однажды, эта научная парадигма, конечно, будет сохраняться. Однако вот что интересно. Социологический подход, который применялся по отношению к искусству и в котором преуспел Тэн, не только приближал к этому предмету, но и от него отдалял. Как это понимать? А так, что при социологическом подходе исследователя интересует не столько само произведение и не столько создавший его автор с его индивидуальными намерениями и замыслами, сколько само общество со своими постоянно изменяющимися настроениями, которые оно проецирует на эти произведения, вкладывая в них и то, что в них может отсутствовать. Нет, не случайно позднее постмодернисты будут очищать искусство от всех этих наслоений, углубляясь в то, что не только было осознано и сказано самим автором, но и в то, что помимо его воли и осознания сказалось. Произведение становится популярным, когда воспринимающие его зрители или читатели ощущают его созвучность их переживаниям и представлениям, и оказывается чуждым, когда этого нет.

Спрашивается, а что же мы тогда познаем в произведении, если мы воспринимаем его в соответствии с установкой социолога? А мы изучаем сознание воспринимающего, причем не только сознание, но и общественное сознание и социальную психологию. Мы изучаем общественные эмоции, но не те эстетические смыслы, что в произведении имеются. Конечно, этого недостаточно. Конечно, это далеко не все, что в произведении имеется. Но это тоже существенно. Ведь это позволяет поставить вопрос о функциях произведения, как и о функциях искусства в целом, причем применительно к каждому историческому периоду. А как нами уже отмечалось выше, когда мы цитировали Э. Дюркгейма, искусство и есть институт, осуществляющий самые разные функции, в том числе и те, которые способен выявить лишь социолог. Если у нас появляется знание о функциях искусства, то одновременно с этим возникает и знание о функционировании искусства как социального института. А это уже кое-что. Большего от социолога и не требуется. Он призван, чтобы внести в познание искусства свою лепту. Остальное следует ожидать от представителей других наук. Таким образом, если сделать заключение, то можно утверждать следующее: социолога интересует знание не столько о самом произведении, сколько о воспринимающей его публике, а значит, об обществе.

\section{Литература}

Валла Л. Об истинном и ложном благе // Эстетика Ренессанса. В 2-х т., т. 1. М.: Искусство, 1981.

Гадамер Х.-Г. Истина и метод. Основы философской герменевтики. М.: Прогресс, 1988.

Гаузенштейн В. Опыт социологии изобразительного искусства. М.: Новая Москва, 1924.

Геннекен Э. Опыт построения научной критики. Эстопсихология. СПб., 1892.

Гердер И.Г. Идеи к философии истории человечества. М.: Наука, 1977.

Герье В. Метод Тэна в литературной и художественной критике // Вестник Европы. 1889 , Выпуск 9.

Гофман А. Социология Эмиля Дюркгейма // Дюркгейм Э. Социология, ее предмет, метод и предназначение. 1995.

Гулыга А. Гердер и его «Идеи к философии истории человечества» // Гердер И.Г. Идеи к философии истории человечества. М.: Наука, 1977.

Дидро Д. Философские исследования о происхождении и природе прекрасного // Дидро Д. Эстетика и литературная критика. М.: Художественная литература, 1980. 
Дидро Д. Эпикуреизм // Боричевский И. Древняя и современная философия науки в ее предельных понятиях. М.-Л., 1925.

Дюбо Ж.-Б. Критические размышления о поэзии и живописи. М.: Искусство, 1976.

Дюркгейм Э. Метод социологии // Дюркгейм Э. Социология. Ее предмет, метод, предназначение. М.: Канон, 1995.

Зедльмайр X. Утрата середины. М.: Прогресс - Традиция, 2008.

Кребер А. Избранное: Природа культуры. М.: РОССПЭН, 2004.

Лало Ш. Введение в эстетику. М., 1915.

Мандельштам O. Собрание сочинений в 4 т., т. 1. М.: Терра, 1991.

Нащокина М. Иконография архитектуры европейского модерна // Европейский символизм. СПб.: Алетейя, 2006.

Страхов Н. Заметки о Тэне // Русский вестник. 1893, № 4.

Тэн И. Путешествие по Италии. В 2-х т., т. 1. М.: Арт - Родник, 2008а.

Тэн И. Путешествие по Италии. В 2-х т., т. 2. Флоренция и Венеция. М.: Арт - Родник, $2008 б$.

Тэн И. Философия искусства. М.: Огиз-Изогиз, 1933.

Тэн И. Тит Ливий. М., 1885.

Тэн И. Происхождение современной Франции. В 5 т. СПб., 1907.

Февр Л. Цивилизация: Эволюция слова и группы идей // Февр Л. Бои за историю. М.: Наука, 1991.

Фриче В. Задачи и проблемы социологии искусства // Вестник Коммунистической Академии. 1926, № 15. - C.3-17.

Фриче В. Социология искусства. М.-Л., ГИЗ, 1926.

Фуко М. Слова и вещи. Археология гуманитарных наук. М.: Прогресс, 1977.

Хейзинга И. Тени завтрашнего дня. Человек и культура. Затемненный мир. СПб., 2010.

Художественная культура в капиталистическом обществе. Л., 1986.

Хренов Н. Визуальная коммуникация: культурологические исследования. М.-СПб.: Центр гуманитарных инициатив, 2019.

Шмит Ф. Предмет и границы социологического искусствоведения. Л., 1927.

\section{References}

Walla L. Ob istinnom i lozhnom blage [About true and false good] // Estetika Renessansa [Aesthetics of the Renaissance]. In 2 vols., vol. 1. M.: Iskusstvo, 1981.

Gadamer H.-G. Istina i metod. Osnovy filosofskoj germenevtiki [Truth and method. Foundations of a philosophical hermeneutics]. M.: Progress, 1988.

Hausenstein V. Opyt sociologii izobrazitel'nogo iskusstva [Experience in the sociology of fine arts]. M.: New Moscow, 1924.

Hennequin E. Opyt postroeniya nauchnoj kritiki. Estopsihologiya [Experience in building scientific criticism. Estopsychology]. St. Petersburg, 1892.

Herder J.G. Idei $k$ filosofii istorii chelovechestva [Ideas on the philosophy of the history of mankind]. M.: Nauka, 1977.

Guerrier V. Metod Tena v literaturnoj i hudozhestvennoj kritike [Teng's method in literary and artistic criticism] // Vestnik Evropy [Bulletin of Europe]. 1889, Issue 9.

Hoffmann A. Sociologiya Emilya Dyurkgejma [Sociology of Emil Durkheim] // Durkheim E. Sociologiya, ee predmet, metod i prednaznachenie [Sociology, its subject, method and purpose]. 1995.

Gulyga A. Gerder $i$ ego "Idei k filosofii istorii chelovechestva» [Herder and his «Ideas on the philosophy of the history of mankind»] // Herder J.G. Idei $k$ filosofii istorii chelovechestva [Ideas on the philosophy of the history of mankind]. M.: Nauka, 1977.

Diderot D. Filosofskie issledovaniya o proiskhozhdenii i prirode prekrasnogo [Philosophical research on the origin and nature of the beautiful] // Diderot D. Estetika i literaturnaya kritika [Aesthetics and literary criticism]. M.: Hudozhestvennaya literatura, 1980.

Diderot D. Epikureizm [Epicureanism] // Borichevsky I. Drevnyaya i sovremennaya filosofiya nauki $v$ ee predel'nyh ponyatiyah [Ancient and modern philosophy of science in its ultimate concepts]. M.-L., 1925.

J.-B. Dubos. Kriticheskie razmyshleniya o poezii i zhivopisi [Critical reflections on poetry and painting]. M., Iskusstvo, 1976.

Durkheim E. Metod sociologii [Method of sociology] // Durkheim E. Sociologiya. Ee predmet, metod, prednaznachenie [Sociology. Its subject, method, purpose]. M., Kanon, 1995. 
Zิ Zedlmire H. Utrata serediny [Loss of the center]. M.: Progress-Tradition, 2008.

Kreber A. Izbrannoe: Priroda kul 'tury [Favorites: The nature of culture]. M., ROSSPEN, 2004.

Lalo S. Vvedenie v estetiku [Introduction to aesthetics]. M., 1915.

Mandelstam O. Sobranie sochinenij [Collected works] in 4 vols., vol. 1. M.: Terra, 1991.

Nashchokina M. Sobranie sochinenij Ikonografiya arhitektury evropejskogo moderna [Iconography of European Art Nouveau architecture] // Evropejskij simvolizm [European symbolism]. St. Petersburg: Aleteia, 2006.

Strakhov N. Zametki o Tene [Notes about Taine] // Russkij vestnik [Russian Bulletin]. 1893, № 4.

Taine H. Puteshestvie po Italii [Travels to Italy]. In 2 vol., Vol. 1., M., Art-Rodnik, 2008a.

Taine H. Puteshestvie po Italii [Travels to Italy]. In 2 vol., Vol. 2., M., Art-Rodnik, 2008b.

Taine H. Filosofiya iskusstva [The philosophy of art]. M., Ogiz-Izogiz, 1933.

Taine H. Tit Livij [Titus Livy]. M.: 1885.

Taine H. Proiskhozhdenie sovremennoj Francii [The origin of modern France]. In 5 vols., St. Petersburg, 1907.

Febvre L. Civilizaciya: Evolyuciya slova i gruppy idej [Civilization: the evolution of a word and a group of ideas] // Fevr L. Boi za istoriyu [Battles for history]. M.: Nauka, 1991.

Foucault M. Slova i veshchi. Arheologiya gumanitarnyh nauk [Words and things. Archeology of humanitarian sciences]. M.: Progress, 1977.

Huizinga J. Teni zavtrashnego dnya. Chelovek i kul 'tura. Zatemnennyj mir [In the shadows of tomorrow. Man and culture. The darkened world]. St. Petersburg, 2010.

Hudozhestvennaya kul'tura v kapitalisticheskom obshchestve [Artistic culture in capitalist society]. L., 1986.

Hrenov N. Vizual'naya kommunikaciya: kul'turologicheskie issledovaniya [Visual communication: cultural studies]. M.-St. Petersburg: Center for Humanitarian Initiatives, 2019.

Fritsche V. Zadachi i problemy sociologii iskusstva [Tasks and Problems of Sociology of Art] // Vestnik Kommunisticheskoj Akademii [Bulletin of the Communist Academy]. 1926, № 15. - Pp.3-17.

Fritsche V. Sociologiya iskusstva [Sociology of art]. M.-L., GIZ, 1926.

Schmitt F. Predmet i granicy sociologicheskogo iskusstvovedeniya [Subject and boundaries of sociological art history]. L., 1927. 